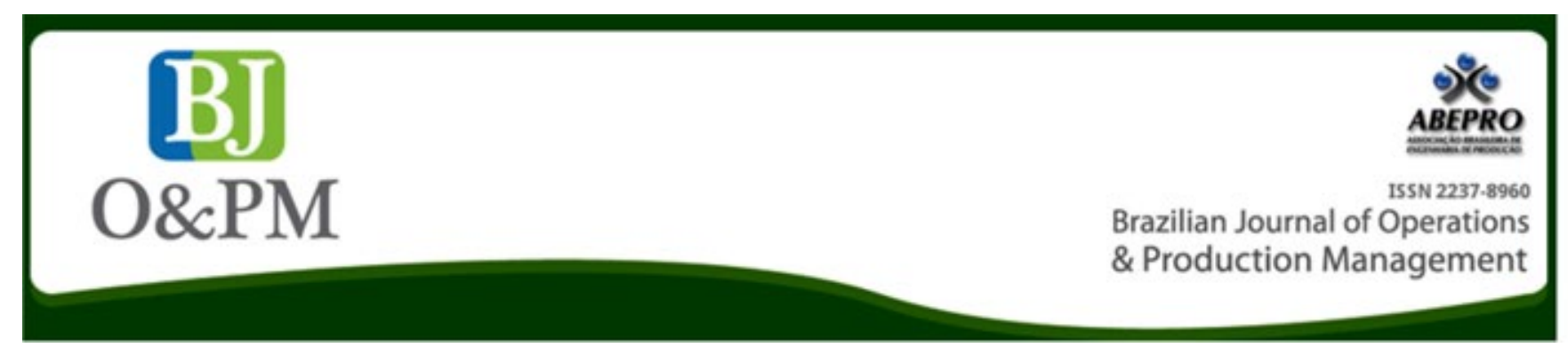

\title{
DESCRIPTIVE AND COMPARATIVE STUDY OF THE PURCHASING ACTIVITY: A CASE STUDY IN A FOOD COMPANY
}

\author{
Letícia Miyuki Aida Endo ${ }^{1}$, Murillo Costa Cerqueira ${ }^{1}$, Gabriel Nery da Silva ${ }^{2}$, Laiane Aparecida Soares Sena \\ Nery², Luiz Teruo Kawamoto Júnior²
}

1 Instituto Federal de Educação, Ciência e Tecnologia de São Paulo

2 Universidade de Mogi das Cruzes

\begin{abstract}
In a scenario of economic and political instability, many companies have being affected by a sense of uncertainty, both small and large companies. In this context, Logistics seeks, among other things, to reduce costs, improve processes and align the supply chain with company strategies. The purchasing sector is increasingly seen as a strategic agent in organizations, not only contributing to cost reduction, but also gaining in terms of productivity, economy and quality. This study aims to analyze and describe the purchasing procedures of a small food company located in the State of São Paulo, and compare it with the literature to see whether there is a matching or a gap between them. The procedure adopted by the study is the case study, based on three pillars: interviews, non-participant observations and documental analysis. The results showed that the company adopts many procedures described in the literature in its purchasing activities, and, with that, it has been performing strategically the purchasing activity and keeping itself competitive within the market; as well as currently there is not a gap between literature and practice.
\end{abstract}

Keywords: Purchasing; Logistics; Material; Purchasing activity; Literature review. 
Brazilian Journal of Operations \& Production Management

Volume 14, Número 1, 2017, pp. 265-271

DOI: 10.14488/BJOPM.2017.v14.n2.a14

\section{INTRODUCTION}

Managing the Supply Chain (SC) is a task which requires dedication and expanded participation of managers and business sectors. Among the various sectors, the purchasing area stands out. It is at the heart of the company-supplier relationship. It is responsible for the acquisition of raw materials, supplies and even contracting services. Baily et al. (2000) say that purchasing is seen as a considerable activity of strategic importance. Its purpose is to supply the needed materials or services in the right quantities and qualities, at the right price and at the right time.

Heinritz et Farrell (1983) state that purchasing is an administrative function, which involves the administration of materials, from the determination of sources and supply routes, passing through the warehouse, to the final delivery at the points of production, as necessary. Also, according to them there are, at all stages, decisions to be made regarding quality, quantity, schedules, origin and cost.

Ballou (2006) says that the purchasing function is fundamental, since in general the purchased items represent between $40 \%$ and $60 \%$ of the cost of the sold product. Currently the purchasing function is seen as the logistics component that has strategic potential in the organization. According to Batista et Maldonado (2008), purchasing processes, over time, has become more complex as well as more dependent on agents who are committed and aware of their role.

The main objective of this study is to analyze the purchasing procedures of a small food company located in the State of São Paulo. The specific objectives are to describe the purchasing activity practiced in the studied company, and to compare the theories brought by the literature with the current purchasing procedure performed in the company to see whether there is a matching or a gap between them.

\section{LITERATURE REVIEW}

\subsection{Supply Chain Management (SCM)}

The supply chain process starts from the customer's first contact with the company, through the information available at the website, catalogs, publicity and advertising until the delivery of the product to the consumer. According to Slack, Brandon-Jones et Johnston (2015), the supply chain is several business units that are connected to provide supplies to end customers. As Poirier et Reiter (1997) also argue that a supply chain is a system from which organizations deliver products to their consumers in an interconnected network. To understand how this system works is a challenge for many managers and rulers, because at every decision it causes a movement of information or materials chained by logistics.
In a search in history for the first logistic terms, it is found in the war, where militaries managed the acquisition, maintenance and transportation of equipment and personnel (Ballou, 2006). The ability to plan or predict the food and equipment necessary for their troops influenced the outcome which civilizations prospered or failed. In business terms, Sampaio (2003) points out that there is a challenge bigger than the military, and it is the business' challenge, since it needs to provide raw materials and finished products in the right quantity, at the right place and at the right time, at the lowest possible cost to meet the demands.

According to Baily et al. (2015), several factors have contributed to the increased importance of purchasing activity in organizations. Some of them are competitive advantages, lean production, technological advancement and greater concentration of purchasing, depending of the business. The challenge of the chain management to generate competitive advantage is the holistic integration within the production chain with the objective of serving the final consumer more efficiently and effectively simultaneously (Pires et al., 2001).

\subsection{Concepts of purchasing}

In logistics the key-activities are marketing, transportation, inventory management and order processing. Support activities are storage, material handling, purchasing, packaging and maintenance of information. In this study the purchasing support activity is considered; it is going to be integrated to a functional area which accompanies the flow of materials and information.

Purchasing models in the purchasing function can be centralized, decentralized or hybrid. According to Mattar's (2011) adaptation, small and independent companies have a simpler structure, as shown in Fig. 1.

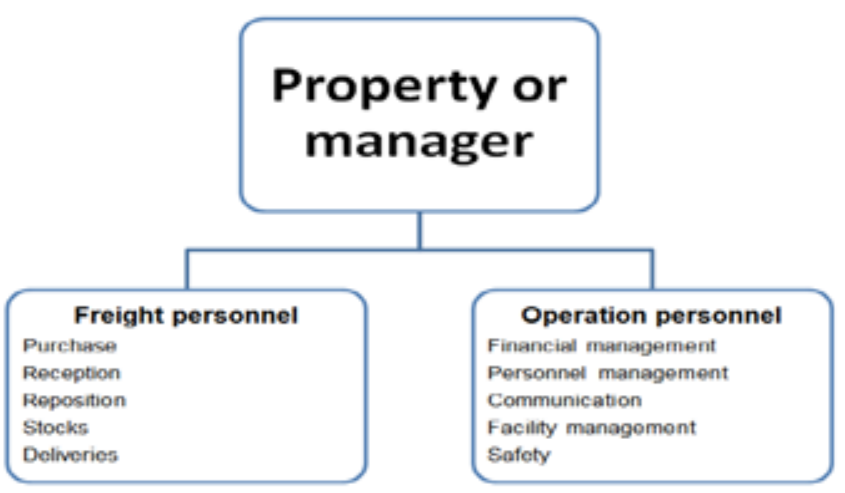

Figure 1. Model of organizational structure of small and independent companies

Source: Adapted from Berman, B. \& Evans, J. R. Retail Management - A strategic approach. 9th ed. New Jersey: Prentice Hall, 2004:275, apud Mattar (2011) 
The centralized purchasing acquisition model above has only one purchasing department. The decentralized purchasing model, as Macohin (2012) explains, is smaller structures in each unit to meet each of them isolatedly. Because of the characteristic of the company in study, it adopts the centralized model. The same author cites some advantages of this centralization, such as the adoption of a standard procedure of purchasing, more efficient service in case something is missing, and it presents better inventory management, since it is a unique structure.

The model has some disadvantages, as it pays more for the ease of replacement and flexibility of acquisition. In this case, there is no economy of scale, raising the costs of products. For Mintzberg (1995), apud These et al. (2010), the centralized structure exists "when all power for decision making is at one place of the organization, ultimately on the hands of only one person". This is what happens in companies with small structures.

According to Dias (2005), the purpose of purchasing is to coordinate the flow of supplies in order to meet the production and acquire materials at the best prices, always looking for better conditions for companies. According to Mattar (2011), in order to understand the needs of the applicant, the purchasing sector should be connected with the internal users, to have a good relationship with the suppliers and be listed with the strategies of the company. And because that, Martins et Atl (2001) argue that the purchasing area should interact with the others, receiving and processing information according to the need, as well as feeding other departments with useful information for decision making. Therefore, as Dias (2005) highlights, the purchasing process is delicate, since those involved in it need to be attentive to price, time, deadline, volume and quality.

Thus, the purchasing function is considered as one of the members of the supply chain aligned with strategic objectives of the company. As Arnold (2015) claims, its role is a specific process, but it requires the involvement of other sectors for product development and financial resources for acquisitions that bring benefits to the company. For Baily et al. (2015), the objectives of the purchasing function are:

a) To provide a safe flow of material and service needs;

b) To ensure the continuity of supplies to sustain effective relationships with suppliers and develop alternative sources of supplies to meet emerging situations;

c) To buy with ethics, in a wise and efficient way, the best value per penny;

d) To manage inventories to provide the best service and the lowest cost for users; e) To keep cooperative relationships with other departments, providing information and advices to ensure the effectiveness of any organization; and

f) To develop employees, procedures, policies and organization to ensure the achievement of the proposed objectives.

Determining procedures to be adopted to start purchasing is essential. According to Ballou (2006), the activities of selecting suppliers, negotiating contracts, comparing prices, evaluating quality and levels of services and receiving forms of raw materials are some ways to make purchasing in a simple way. However, there is also an expanded view of purchasing functions (Slack, Brandon-Jones, Johnston, 2015), as Figure 2 shows.

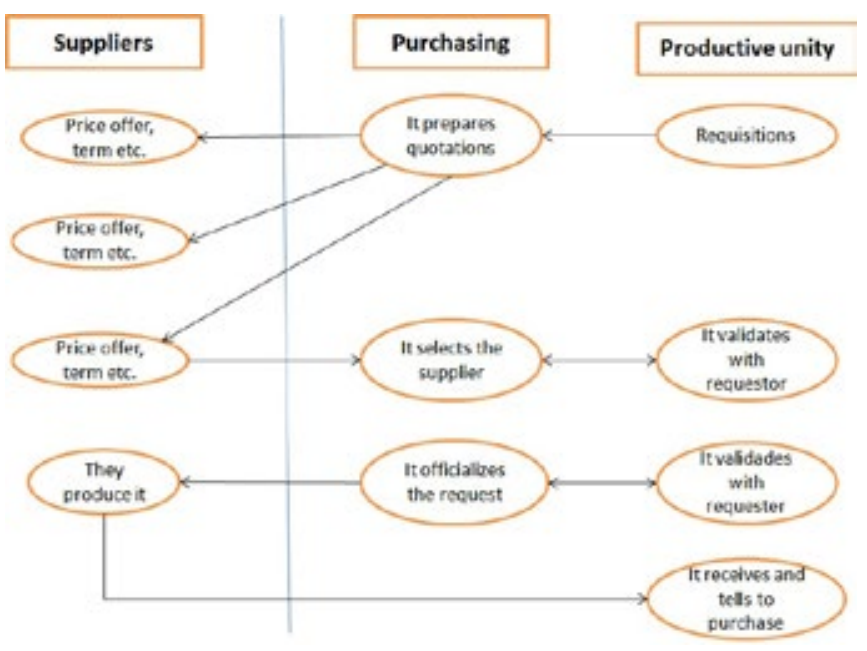

Figure 2. Purchasing functions

Source: Adapted from Slack, Brandon-Jones et Johnston (2015).

Other procedures also adopted, as Arnold (2015) defines as the 'Cycle of Purchasing', are:

a) To receive and analyze the purchase requisitions;

b) To select supplier: to issue requests for quotations, receive and analyze quotes and then select the right supplier;

c) To determinate the right price;

d) To issue purchase orders;

e) To do a monitoring to guarantee that the deadline be fulfilled;

f) To receive and accept goods; and

g) To approve the invoice for payment of suppliers. 
For Viana (2015, p.177), the procedures are listed in several stages:

a) Process preparation;

b) Purchasing planning;

c) Suppliers selection;

d) Competition;

e) Suppliers hiring; and

f) Delivery control.

The theories adopted by the authors in the area of materials management and purchasing (Dias, 2005; Ballou, 2006; Arnold, 2015; Baily et al., 2015; Slack, Brandon-Jones et Johnston, 2015; Viana, 2015) form the base of the foundation concerning the objectives, amounts and functions of purchasing within a company, linked to logistics.

However, some performance indicators which are considered in the purchasing process should not be forgotten. It is these notes which will give greater credibility to supplier, since the company that owns a purchasing organization seeks to identify those performances. Leenders et al. (2006), apud Neto (2011), suggests as indicators of purchasing: punctuality of deliveries, number of rejected lots, time-prices curve practiced versus certain market indexes, indicators of market conditions and price performance and; when possible, reviews of the purchasing history or comparisons with other businesses. Finally, as Lima et Marx (2008) explain, the effectiveness of the purchasing process is the way how it is managed by the buyer, who puts his skills and qualifications developed over time into practice. Thus, to analyze indicators and processes aligned with company strategies leads the experienced buyer to be effective in the purchasing function.

\section{METHOD}

For the accomplishment of this study it was adopted an exploratory-descriptive approach of qualitative nature with a temporal cut in 2016, year of data collection, seeking information for analysis of the purchasing process. With this, it constituted a case study and the unit-case was a small food business located in the State of São Paulo, besides the adopting of different techniques for data collection, since this is the basic principle to be followed when the case study is used (Gil, 2010).

Once the unit-case is defined, it follows some of the protocols mentioned by Gil (2010, p.117): formulation of the problem; selection of cases; protocol elaboration; data collection. The field procedures of this study are the information collected; this information is obtained through interviews and observations.

The preparation of the report was done simultaneously to the non-participant observation, by collecting data that were annotated at during the act of the research. The interview took place with the person responsible for the purchasing in the studied company. The non-participant observation intended to understand a little about the purchasing process that it performs, making comparisons of the collected in the study with the theoretical reference. After data collection, data analysis was performed, as shown by Yin (2010), developing a case description, which is a strategy to develop a descriptive structure in order to organize the case study.

\section{THE CASE STUDY}

In order to produce safe food according to the Agência Nacional de Vigilância Sanitária (ANVISA - National Health Surveillance Agency), industries should maintain strict quality control at all stages of production, such as buying good raw materials, using appropriate methods of processing, storage and distribution. In this case study we observe the purchasing process of a food company during one month (March, 2016), collecting data by means of a questionnaire applied for the responsible of the sector.

To start the survey it was necessary to know who was in charge of the purchasing activity, his position and for how long he works in the company. In this case he is the owner, with twenty years of experience managing it. Since he is the buyer responsible for his own acts, it is noted here one first common aspect with the literature, because his responsibility is accompanied by the indispensable authority, and, in this sense, Vianna (2015, p. 179) says that 'the buyer without authority will never be able to carry out his business successfully, because he cannot, for example, be responsible for negotiation with suppliers'.

On the other hand, as he has authority, one of the disadvantages of that is the large responsibility, as for example the dependency on him when negotiations happen along with all the other responsibilities of the company. Furthermore, in this case, the purchasing function is part of its administration as a whole.

It was asked him which is the importance of the purchasing of raw material for the company and, according to his point of view, he answered that it is to know how to buy the product, which means to search for better prices and better offers. In the company the purchase of raw material depends on the quantity of orders or sales at the counter, re- 
calling that only the necessary is bought, since the company is not in a position to keep stocks or to have waste problems.

Baily et al. (2015, p. 85) say that 'the purchasing function is important whenever the organization spends a significant portion of its revenue on the procurement of the goods and services needed for the businesses'. In this case, the handicraft production depends of the acquisition of raw materials for the elaboration of the final product. It is interesting to note how Arnold (2015) says that the first concern in terms of the purchasing function is what to buy and it is not really anything simple. Therefore, he defends some specifications that can be used before to purchase, such as quantity requirement. Thus, the author states that 'quantity is important because it will influence how the product will be designed, specified and manufactured' (Arnold, 196, 2015). Therefore, the quantity to be purchased normally will be to meet the need for production.

We also sought to know which the relevant factor was at the time of the acquisition of raw material. Then the buyer revealed that it is the quality. Baily et al. (2015) outline key-purchasing variables such as quality, right quantity, deadlines, sources of supply, price and purchasing negotiation. Since, according to the author, it provides compliance or adjustment of the purpose, that is, in the view of the consumer 'this is a product of quality'. When it comes to a company with a tradition for more than twenty years, what keeps it within the market is customer demand and satisfaction; thus, the quality of the raw material is a prime factor.

Following this reasoning, Arnold (2015), as said before, establishes the categories of specifications, one of them being the functional requirements. Within this category the functional specification is described, such as a combination of brand, physical and chemical specification, material and method of production, and performance. At the end, the end user is the one who will evaluate it: 'quality is related to the expectation of product performance' (Arnold, 2015, p.198). As a result of this quest for quality and satisfaction, there is a price that reflects in the costs of the material purchased.

The company adopts the strategy of differentiation, which are the confectionary cakes and the deep fried handcrafted snacks. It results in a more elaborate final product, higher price compared to the competition and, therefore a more demanding target audience. Consequently, the purchasing strategy focuses on the quality of the raw material and subsequently the search for the best price.

According to Leenders et al. (2006) apud Senapeschi Neto et Godinho Filho (2011), the purchasing management should meet some premises so it will have a strategic con- tribution, such as seeking to buy items at the lowest, and seeking alignment with the company's strategy, which, in this case, is the differentiation by quality.

An important point mentioned by Fontolan Luciano (2011) is that the positioning of the company regarding the purchasing process will reflect directly in the negotiations with its suppliers, and the result of these activities will dictate the market value of the products offered, contributing to the positioning of the company before the competition.

In the interview some criteria for choosing the suppliers were discussed, such as how to have a specific product or similar quality, price and deadline for payment and delivery. Purchasing is made with different suppliers; however, the most consolidated suppliers distribute specific raw materials to the company and each of them has a deadline for deliveries and payments. Yet the wholesale and retail purchasing are those performed with suppliers located in the surrounding cities, and they are usually done at sight.

Regarding the updating of the suppliers' register, considering that Viana (2015) and Arnold (2015) say that it is important, we asked him about it, and he answered that his updating is based on the tripod: quality, price and time.

The disadvantages of non-updating pointed out by Baily et al. (2015) is the lack of knowledge in terms of the supplier performance, the judgment of its capacity and the monitoring of competitive prices. According to Leenders et al. (2006), apud Neto (2011), they suggest as indicators of the perspective of supplier evaluation: punctuality of deliveries; number of rejected lots; curve of prices practiced versus certain market indexes; indicators of market conditions and; price performance. Taking into account the authors 'evaluation of the suppliers' selection criteria, there is a gap to be analyzed later in the purchasing activity.

The company works with the minimum inventory possible, because it is a food manufacturing company. The price survey is daily in the suppliers that own certain products and price comparisons are made in parallel to the purchasing. Although there is no notation or quotation procedure, prices are memorized by the buyer. If a larger quantity is needed, it is required to the purchasing manager.

Regarding the systematic way to perform a quotation evaluation (which is normally previewed), although this company does not do it as predicted, Viana (2015) affirms that the fundamental principles of purchasing are the analysis of quotations and investigation of the supply sources. 
Brazilian Journal of Operations \& Production Management

Volume 14, Número 1, 2017, pp. 265-271

DOI: 10.14488/BJOPM.2017.v14.n2.a14
Now, considering the facts related by the interviewee, Table 1 was elaborated. In this table, the purchasing function activities, defined in the literature by the authors in comparison with the applied interview and observation, can be noticed.

Table 1. Comparison of the theoretical references with the current purchasing procedure performed in the company

\begin{tabular}{|c|c|}
\hline \multicolumn{2}{|l|}{ Purchasing cycle (Arnold, 2015) } \\
\hline To receive and to analyze the purchase requirements & Yes \\
\hline $\begin{array}{l}\text { To select suppliers, to receive and to analyze the } \\
\text { quotations }\end{array}$ & No \\
\hline To determinate the correct price & Yes \\
\hline To issue purchase orders & No \\
\hline $\begin{array}{l}\text { To do a monitoring to ensure compliance with the } \\
\text { deadline }\end{array}$ & Yes \\
\hline To receive and to accept goods & Yes \\
\hline To approve the invoice for the payment of suppliers & Yes \\
\hline \multicolumn{2}{|l|}{ Purchasing procedures (Viana, 2015) } \\
\hline Process preparation & Yes \\
\hline Purchasing planning & Yes \\
\hline Suppliers selection & Yes \\
\hline Competition & No \\
\hline Suppliers hiring & Yes \\
\hline Delivery control & Yes \\
\hline \multicolumn{2}{|c|}{$\begin{array}{l}\text { Function of purchasing (Slack, Brandon-Jones, } \\
\text { Johnston, 2015) }\end{array}$} \\
\hline To prepare quotations & No \\
\hline To offer prices and deadlines & Yes \\
\hline To select suppliers & Yes \\
\hline To make official the order & Yes \\
\hline
\end{tabular}

Source: authors based on Arnaldo, (2015), Slack, Brandon-Jones et Johnston, (2015) and Viana's, (2015) studies.

Finally, we questioned him in terms of what the main difficulty is in the process of buying raw material and he stated the increase in the prices of raw materials and the difficulty in terms of including it within the value of the final product, since the company works with quality items and depends on some brands of food products. About that, Baily et al. (2015, p. 19) say: "whatever the proportion, it should be noted that a $5 \%$ increase in the cost of materials that is not recomposed in the sale price can have a similarly dramatic negative effect"; and what Arnold (2015, p. 205) says is: "price is not the only factor that influences purchasing decisions, but, under equal circumstances, it is the most important". That is, any savings made in the cost of purchasing have a direct influence on profits. Due to this difficulty and complexity characteristic in relation to prices and costs, a specific study on it is necessary.

Finally, the hypothesis raised at the beginning of this study in terms of how the purchasing activity is performed in this company and whether it has similarities/coherence or not be- tween it and the theory met in this discussion. However, it is necessary to deepen the studies regarding suppliers, quotations and final cost analysis from the acquired raw material.

\section{FINAL CONSIDERATIONS}

Due to the facts presented in this study, it is understood that, according to literature, the purchasing activity performed in the company meets the needs of the activity. Furthermore, in a simplified and balanced way, it follows the economic scenario and adapts itself to the demand. Thus there is no exaggeration in the purchasing; however, it is important to remember that, in order to do a price survey it is fundamental.

The work resulted in a practical contribution, since after the survey it was possible to point out some purchasing techniques that were not being used. Furthermore, we noted some limitations for the study and for the company, such as the fact that there was only one interviewee - the owner of a family business - and that the organization depends of one only buyer.

According to the study, we can conclude that the literature matches the procedures performed in the company and vice versa, and also that the fulfillment of the procedures registered in the literature can contribute for the success of the company when it performs its purchasing activity.

For future work we suggest the idea of implementing improvements in the purchasing activity in relation to its suppliers and in conjunction with the inventory sector.

\section{REFERENCES}

ANVISA (Agência Nacional de Vigilância Sanitária). Guia de alimentos e vigilância sanitária. Available on <http://www. anvisa.gov.br/alimentos/guia_alimentos_vigilancia_sanitaria. pdf $>$. Accessed on 04.02.2016.

Arnold, J. R. T. (2015). Administração de Materiais. São Paulo, Atlas.

Baily, P.; Farmer, D.; Jessop, D.; Jones, D. (2015). Compras: princípios e administração. São Paulo: Atlas.

Ballou, R. H. (2006). Gerenciamento da cadeia de suprimentos/logística empresarial. 5. ed. Porto Alegre: Bookman.

Batista, M. A. C.; Maldonado, J. M. S. V. (2008). O papel do comprador no processo de compras em instituições públicas de ciência e tecnologia em saúde (C\&T/S). Rev. Adm. Pública, Rio de Janeiro, Vol. 42, No. 4, pp. 681-699.

Dias, M. A. P. (2005). Administração de Materiais. São Paulo: Atlas. 
Fontolan, L.; Adriane, S. A. (2011). O uso da Estratégia no setor de compras para obter vantagem competitiva para as empresas. São Paulo.

Gil, A.C. (2010). Como Elaborar Projetos de Pesquisa. 5a ed. São Paulo: Atlas.

Heinritz, S. F.; Farrell, P. V. (1983). Compras: princípios e aplicações. São Paulo: Atlas.

Lima, J. C. S.; Marx, R. (2008). A configuração da área de compras e o trabalho do comprador nas montadoras: novas atribuições e perfil. Revista GEPROS - Gestão da Produção, Operações Sistemas. Ano 3, No. 1.

Macohin, G. (2012). Compras, contratações. 1. ed. Curitiba: lesde Brasil.

Martins, P. G.; Alt, P. R. C. (2001). Administração de Materiais e Recursos Patrimoniais. São Paulo: Saraiva. sil.

Mattar, F. N. (2011). Administração de varejo. Elsevier Bra-
Neto, A. S.; Filho, Moacir, G. (2011). A evolução da gestão de compras em uma empresa do segmento de material escolar: estudo de caso longitudinal. Prod. Vol. 21, No. 1.

Senapeschi Neto, A.; Godinho Filho, M. (2011). A evolução da gestão de compras em uma empresa do segmento de material escolar: estudo de caso longitudinal. Production, São Paulo, Vol. 21, No. 1, pp. 76-93.

Slack, N.; Brandon-Jones, A.; Johnston, R. (2015). Administração de Produção. 4. ed. São Paulo: Atlas.

These, D.; Matos, S. D.; Brambilla, F.R. Vantagens e Desvantagens da Centralização de Compras no Varejo. Available on <www.ingepro.com.br/Publ_2010/Julh/259-729-1-PB.pdf $>$. Accessed on 03.30.2016.

Viana, J. J. (2015) Administração de Materiais: um enfoque prático, 1. ed. São Paulo: Atlas.

Yin, R.K. (2010). Estudo de caso: planejamento e métodos. 4a ed. Porto Alegre: Bookman. 